\title{
GQIM-based Model for Optimizing the Professional Training Program of PETOE
}

\author{
Liu Yang ${ }^{1, a}$, Zhigang $\mathrm{Hu}^{1, b}$, Shenbin Ren ${ }^{1, c}$, Lin Jiang ${ }^{1, \mathrm{~d}}$, Meiguang Zheng ${ }^{1, \mathrm{e}}$ \\ ${ }^{1}$ School of Software, Central South University, Changsha 410075, China

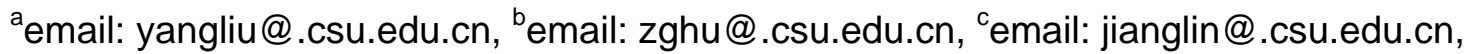 \\ demail: rsb@.csu.edu.cn, eemail: zhengmeiguang@.csu.edu.cn
}

Keywords: Professional Training Program; GQM Model; Optimal Model; PETOE

\begin{abstract}
This paper proposes the GQM model for the professional training program of PETOE based on the goal of PETOE, which contains the national goal, the university goal and the professional goal. Making full use of the characteristics of GQM approach that can goal-oriented refine and quantitative analyze, the method for formulating and evaluating the professional training program of PETOE based on the GQM model is proposed in this paper. By the quantitative metric and analysis, the method for adjusting and optimizing the professional training program of PETOE is presented. The application results show that this GQM-based optimization model can make clear guidance to design, improve and optimize the professional training program of PETOE by quantitative metric values. This not only avoids adjusting the professional training program of PETOE blindly and arbitrarily, but also effectively helps for the universities to implement the PETOE.
\end{abstract}

\section{Introduction}

A Plan for Educating and Training Outstanding Engineers (PETOE) [1] was launched in June 2011 by Ministry of Education, aiming to train up high-quality engineering technical professionals with strong innovative ability for the engineering and industrial fields in order to meet the requirements of our social and economic progress. Under the background of PETOE, designing, improving and optimizing the professional training program of PETOE is the important foundation to implement PETOE by colleges and universities. Recently, Professor Jian Lin [1-3] at Engineering Education Research Center of Tsinghua University studied personnel training mode and training program of PETOE. He stressed the importance of professional training program and curriculum system to implement PETOE, and proposed four principles for drawing up professional training program: (1) Identify personnel training objective suitable for the certain universities; (2) Pay full attention to the unique personnel training; (3) Focus on the background of industry and enterprise; (4) Stress on the reform and innovation of personnel training mode [1].

This paper focus on how to design, improve and optimize the professional training program according to the objective of PETOE. A metric model of professional training program for formulating and evaluating professional training program is proposed based on Goal-Question-Metric approach (GQM). In this paper, a method to describe, measure and quantitatively analyze professional training program of PETOE is presented to direct the process of designing, improving and optimizing the professional training program, so as to achieve the goal of training outstanding engineers.

\section{GQM Approach}

GQM approach [4] is a goal-oriented measurement paradigm used in a software project and aims to improve the process and product development. It was originally developed by Basili and Weissin at University of Maryland in America during the 1970s to 1980s. GQM is a top-down approach and starts with the goals of identified through questions and concludes by identifying the metrics that bring the answers to the questions made. In addition, the GQM process is described as goal 
generates question, questions generates metrics, and it helps to characterize, evaluate, predict and improve the software developing process.

As domestic and international studies indicated that GQM is not only a goal-oriented method of software process metric, but also a method to analyze and solve the problems suitable for scientific management. GQM has a three-layered framework, including Goal Layer, Question Layer and Metric Layer. There are three steps to apply this framework: (1) Identify the Goal (G); (2) Define the Questions (Q), which refine a series of specific problems to describe and evaluate the process of achieving the goal. (3) Build the models of Metric (M), which design the metric models and metric methods of quantitative calculation based on the specific questions defined in step 2.

GQM approach can effectively convert the abstract goal into specific problems, and help to direct the process improvement by quantitative analysis of metric. Therefore, GQM approach can also give directions to design, improve and optimize the professional training program, which is one of the significant issues to implement PETOE.

\section{The GQM Model for Professional Training Program of PETOE}

\section{A. Training Goal}

There are two principles to identify the training goal of professional training program of PETOE [2]. On the one hand, the training goal should conform to the general goal of PETOE; On the other hand, it should reflect the universities' own characteristics. Therefore, the training goals of PETOE in different specialties in different universities are not the same.

In order to identify the training goal of professional training program of PETOE in a certain university, the national-level goal, the university-level goal and professional-level goal must be concerned, according to the common standards, the university standards and the industry standards of PETOE.

\section{B. Training Goal and Evaluation Indicators Model}

After identifying the training goal, the evaluation indicators can be established to signal whether the professional training program meets to the demand of training goal or not. This section builds the training goal and evaluation indicators model based on the three-level training goals of the national-level, the university-level and professional-level, by taking advantages of GQM to manage the whole process by goal-oriented refinement. The model is shown as.1.

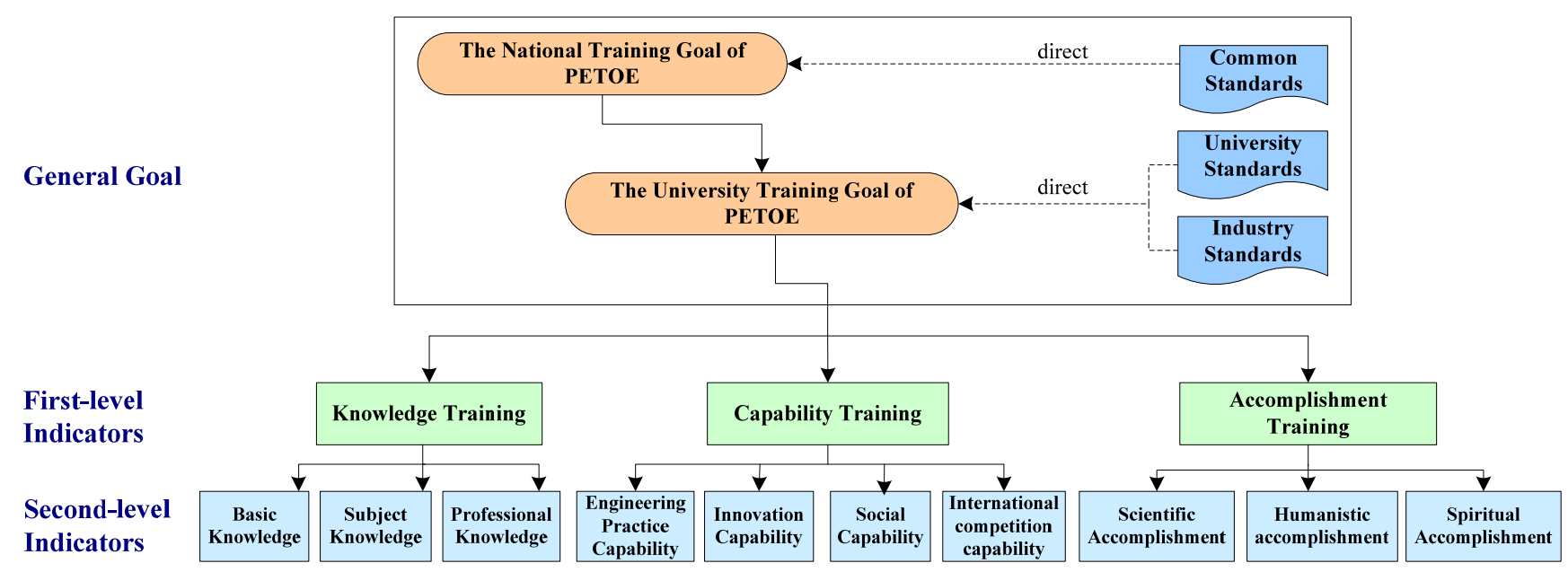

Fig.1. Training goal and evaluation indicators model

The training goal and evaluation indicators model contains three layers: General Goal Layer, First-level Indicator Layer and Second-level Indicator.

(1) General Goal Layer: The general training goal of the PETOE is identified according to common standards, combining with the university standards and industry standards. The common standards are directed by the national training goal of PETOE, the university standards reflect the personnel training position and their characteristics of the university, and the industry standards 
reflect the characteristics and demands of the industry.

(2) First-level Indicator Layer: The common standards of PETOE emphasize that outstanding engineers must be competitive and potential in knowledge, capability and accomplishment. So knowledge, capability and accomplishment are the first-level indicators to measure whether the curriculum system and the teaching plan of the training program is reasonable or not, that is, to make sure that the curriculum system and the teaching plan focus on the training of knowledge, capability and accomplishment.

(3) Second-level Indicator Layer: The second-level indicators are refinement of the first-level indicators. Different universities can make different details from the first-level indicators according to their university standards and industry standards. In the Fig.1, the knowledge training of first-level indictor is divided into the training of basic knowledge, subject knowledge and professional knowledge, the capability training of first-level indictor is divided into the training of engineering practice capability, innovation capability, social capability and international competition capability, and the accomplishment training of first-level indictor is divided into the training of scientific accomplishment, humanistic accomplishment and spiritual accomplishment.

In the above training goal and evaluation indicators model shown in Fig.1, the general goal is the foundation of establishing the curriculum system and teaching plan in professional training program of PETOE, and the first-level indicators and second-level indicators are the basis evaluations to measure whether the curriculum system and teaching plan can achieve the training goal or not.

\section{Building the GQM model for professional training program of PETOE}

The above training goal and evaluation indicators model provide the qualitative analysis method for formulating and evaluating the professional training program of PETOE. In order to provide the quantitative analysis method for further designing, improving and optimizing the professional training program, the GQM model for professional training program of PETOE is presented in this section. This GQM model establishes the relationship between the training goal of knowledge, capability \& accomplishment and the corresponding metric elements, and then find out the problems existed in the professional training program by quantitative evaluation of GQM.

Table 1 shows the GQM model for professional training program of PETOE. According to the three steps to implement GQM approach presented in Section 2, this model contains four layers: General Goal Layer, Detailed Goal Layer, Question Layer and Metric Layer.

Table 1. The GQM model for professional training program of PETOE

\begin{tabular}{|c|c|c|c|}
\hline General Goal & Detailed Goal & Question & Metric \\
\hline \multirow{17}{*}{$\begin{array}{l}\text { Knowledge } \\
\text { Training } \\
\text { Capability } \\
\text { Training } \\
\text { Accomplishment } \\
\text { Training }\end{array}$} & \multirow{4}{*}{$\begin{array}{c}\text { General } \\
\text { Education } \\
\text { (GE) }\end{array}$} & \multirow{2}{*}{ Have set up courses related to GE? } & Credits of GE Courses $\left(\mathrm{C}_{\mathrm{GE}}\right)$ \\
\hline & & & GE Courses Ratio of Total Courses $\left(\mathrm{R}_{\mathrm{GE}}\right)$ \\
\hline & & \multirow{2}{*}{ Have set up practice in GE? } & Practice Credits of GE Courses ( $\mathrm{C}_{\mathrm{PGE}}$ ) \\
\hline & & & Practice Ratio of GE Courses ( $\left.\mathrm{R}_{\mathrm{PGE}}\right)$ \\
\hline & \multirow{4}{*}{$\begin{array}{c}\text { Subject } \\
\text { Education } \\
\text { (SE) }\end{array}$} & \multirow{2}{*}{ Have set up courses related to SE? } & Credits of SE Courses $\left(\mathrm{C}_{\mathrm{SE}}\right)$ \\
\hline & & & SE Courses Ratio of Total Courses $\left(\mathrm{R}_{\mathrm{SE}}\right)$ \\
\hline & & \multirow{2}{*}{ Have set up practice in SE? } & Practice Credits of SE Courses (C $\left.{ }_{\mathrm{PSE}}\right)$ \\
\hline & & & Practice Ratio of SE Courses ( $\mathrm{R}_{\mathrm{PSE}}$ ) \\
\hline & \multirow{4}{*}{$\begin{array}{l}\text { Professional } \\
\text { Education } \\
\text { (PE) }\end{array}$} & \multirow{2}{*}{ Have set up courses related to PE? } & Credits of PE Courses $\left(\mathrm{C}_{\mathrm{PE}}\right)$ \\
\hline & & & PE Courses Ratio of Total Courses $\left(\mathrm{R}_{\mathrm{PE}}\right)$ \\
\hline & & \multirow{2}{*}{ Have set up practice in PE? } & Practice Credits of PE Courses $\left(\mathrm{C}_{\mathrm{PPE}}\right)$ \\
\hline & & & Practice Ratio of PE Courses $\left(\mathrm{R}_{\mathrm{PPE}}\right)$ \\
\hline & \multirow{4}{*}{$\begin{array}{l}\text { Personality } \\
\text { Cultivation } \\
\text { (PC) }\end{array}$} & \multirow{2}{*}{ Have set up courses related to PC? } & Credits of PC Courses $\left(\mathrm{C}_{\mathrm{PC}}\right)$ \\
\hline & & & PC Courses Ratio of Total Courses $\left(\mathrm{R}_{\mathrm{PC}}\right)$ \\
\hline & & \multirow{2}{*}{ Have set up selective courses (SC)? } & Credits of Selective Courses $\left(\mathrm{C}_{\mathrm{sc}}\right)$ \\
\hline & & & SC Ratio of Total Courses $\left(\mathrm{R}_{\mathrm{SC}}\right)$ \\
\hline & $\begin{array}{c}\text { Engineering } \\
\text { Practice } \\
\text { Training(EAT) }\end{array}$ & Have stressed on EAT? & EAT Ratio of Total Practice Training ( $\mathrm{R}_{\mathrm{PEAT}}$ ) \\
\hline
\end{tabular}

(1) General Goal: Identify the general goal of professional training program of PETOE, including the knowledge training goal, the capability training goal and the accomplishment training goal. 
(2) Detailed Goal: Refine the general goal to detailed implemental goals of curriculum system and teaching plan. As shown in Table 1. The general goal is refined into five detail implemental goals, including General Education (GE), Subject Education (SE), Personality Education (PE), Personality Cultivation (PC) and Engineering Ability Training (EAT).

(3) Problem: Ask questions about the detailed goals, that is, the questions about GE, SE, PE, PC and EAT in the curriculum system and teaching plan.

(4) Metric: Define the metric models to calculate the quantitative metric values so as to answer the above questions. Moreover, combining with the evaluation indictors and the quantitative metric values, the problems existed in the curriculum system and teaching plan can be found out, and then the improvement can be carried out to solve those problems.

\section{Practice of Formulating and Optimizing the Professional Training Program of PETOE based on GQM Model}

This section takes the major of software engineering in Central South University (CSU) as an example, which is the pilot major of PETOE. CSU is one of the first batches of universities of PETOE, and it pays attention to not only the training of knowledge, capability and accomplishment, but also the personality cultivation and the engineering practice.

\section{A. Training goal and indicators of the SE professional training program of PETOE}

Undergraduate School of CSU made the request of revising training program and optimizing curriculum system to implement PETOE. The specific requirements are as follows: (1) The total credits of the pilot major during the four years is about 188; (2) The selective courses ratio of the total courses is above 35\%; (3) The practice courses ratio of the total courses is above 30\%; (4) The extracurricular credits is not less than 10 . The above requirements give the indicators of evaluation.

The requirements also indicate that CSU emphasize the key course teaching links, including engineering training, personality cultivation, practice teaching and extracurricular study.

\section{B. Evaluation and Analysis of the SE professional training program of PETOE}

All of the majors have their own professional training program before making the above specific requirements for PETOE, but most of them cannot meet the requirements. Therefore, the existed professional training program must be adjusted and optimized to meet the requirements. By applying the GQM model for professional training program of PETOE based on the practical data from the professional training program of software engineering major, we can calculate the metric values by the metric model and then compare with the indicators showed in the requirements, so as to find out the problems and to direct the adjustment and optimization of the SE professional training program of PETOE.

Take software engineering major of PETOE as an example, the existed SE professional training program does not meet the requirements, so we adjust and optimize it based on the GQM model for SE professional training program of PETOE shown in Table 1, and Table 2 shows both the metric values before adjustment and after adjustment with the total credits at 190.5 .

From the Table 2, we can evaluate the SE professional training program of PETOE based on the indicators made by the Undergraduate School of CSU. Fig.2 shows the key course teaching links, including selective courses, practice teaching and extracurricular study.

The Fig. 2 clearly indicates the defects of the current SE professional training program before adjustment: (1) The credit of selective courses is only 47.5 and its ratio of total courses is $24.9 \%$. Obviously, it is almost $10 \%$ less than the requirement of $35 \%$, so it is difficult for the current SE professional training program to achieve the goal of personality cultivation; (2) the credit of practice teaching is 47.5 and its ratio of total courses is $24.9 \%$. Obviously, it is also less than the requirement of $30 \%$, so it is difficult for the current SE professional training program to achieve the goal of practice training; (3) the credit of extracurricular study is 8 , and it is less than the requirement of 10 , so it is also unable to achieve the goal of personality cultivation. 
Table 2 The GQM metric of the SE professional training program of PETOE

\begin{tabular}{|c|c|c|c|}
\hline $\begin{array}{l}\text { Detailed } \\
\text { Goal }\end{array}$ & Question & $\begin{array}{l}\text { Metric Values } \\
\text { Before } \\
\text { Optimization }\end{array}$ & $\begin{array}{l}\text { Metric Values } \\
\text { After } \\
\text { Optimization }\end{array}$ \\
\hline \multirow{4}{*}{$\begin{array}{l}\text { General Education } \\
\text { (GE) }\end{array}$} & \multirow{2}{*}{ Have set up courses related to GE? } & $\mathrm{C}_{\mathrm{GE}}=63$ & $\mathrm{C}_{\mathrm{GE}}=54$ \\
\hline & & $\mathrm{R}_{\mathrm{GE}}=33.1 \%$ & $\mathrm{R}_{\mathrm{GE}}=28.9 \%$ \\
\hline & \multirow{2}{*}{ Have set up practice in GE? } & $\mathrm{C}_{\mathrm{PGE}}=6.5$ & $\mathrm{C}_{\mathrm{PGE}}=8.5$ \\
\hline & & $\mathrm{R}_{\mathrm{PGE}}=10.3 \%$ & $\mathrm{R}_{\mathrm{PGE}}=11.8 \%$ \\
\hline \multirow{4}{*}{$\begin{array}{l}\text { Subject Education } \\
\text { (SE) }\end{array}$} & \multirow{2}{*}{ Have set up courses related to SE? } & $\mathrm{C}_{\mathrm{SE}}=56.5$ & $\mathrm{C}_{\mathrm{SE}}=62.5$ \\
\hline & & $\mathrm{R}_{\mathrm{SE}}=29.7 \%$ & $\mathrm{R}_{\mathrm{SE}}=33.3 \%$ \\
\hline & \multirow{2}{*}{ Have set up practice in SE? } & $\mathrm{C}_{\mathrm{PSE}}=5$ & $\mathrm{C}_{\mathrm{PSE}}=15$ \\
\hline & & $\mathrm{R}_{\mathrm{PSE}}=2.6 \%$ & $\mathrm{R}_{\mathrm{PSE}}=7.9 \%$ \\
\hline \multirow{4}{*}{$\begin{array}{l}\text { Professional } \\
\text { Education } \\
\text { (PE) }\end{array}$} & \multirow{2}{*}{ Have set up courses related to PE? } & $\mathrm{C}_{\mathrm{PE}}=63$ & $\mathrm{C}_{\mathrm{PE}}=64$ \\
\hline & & $\mathrm{R}_{\mathrm{PE}}=33.7 \%$ & $\mathrm{R}_{\mathrm{PE}}=33.6 \%$ \\
\hline & \multirow{2}{*}{ Have set up practice in PE? } & $\mathrm{C}_{\mathrm{PPE}}=36$ & $\mathrm{C}_{\mathrm{PPE}}=36$ \\
\hline & & $\mathrm{R}_{\mathrm{PPE}}=57.1 \%$ & $\mathrm{R}_{\mathrm{PPE}}=56.2 \%$ \\
\hline \multirow{4}{*}{$\begin{array}{l}\text { Personality } \\
\text { Cultivation } \\
\text { (PC) }\end{array}$} & \multirow{2}{*}{ Have set up courses related to PC? } & $\mathrm{C}_{\mathrm{PC}}=8$ & $\mathrm{C}_{\mathrm{PC}}=10$ \\
\hline & & $\mathrm{R}_{\mathrm{PC}}=4.2 \%$ & $\mathrm{R}_{\mathrm{PC}}=5.3 \%$ \\
\hline & \multirow{2}{*}{ Have set up selective courses (SC)? } & $\mathrm{C}_{\mathrm{SC}}=48$ & $\mathrm{C}_{\mathrm{SC}}=70$ \\
\hline & & $\mathrm{R}_{\mathrm{SC}}=25.2 \%$ & $\mathrm{R}_{\mathrm{SC}}=36.8 \%$ \\
\hline \multirow{2}{*}{$\begin{array}{l}\text { Engineering Practice } \\
\text { Training(EAT) }\end{array}$} & \multirow{2}{*}{ Have stressed on EAT? } & $\mathrm{C}_{\mathrm{PEAT}}=47.5$ & $\mathrm{C}_{\mathrm{PEAT}}=59.5$ \\
\hline & & $\mathrm{R}_{\mathrm{PEAT}}=24.9 \%$ & $\mathrm{R}_{\mathrm{PEAT}}=31.2 \%$ \\
\hline
\end{tabular}

\section{Adjusting and Optimizing the SE professional training program of PETOE}

After the above evaluation and analysis of the SE professional training program of PETOE, we clearly understand its defects according to the requirements. Therefore, we adjust and optimize the SE professional training program of PETOE by the following measures:

(1) Reduce the general education courses and increase the subject education courses. For instance, the courses of Physics and Electronic circuit are cancelled, which are irrelevant to the software engineering. Meanwhile, the courses of Architecture and Platform Techniques in Software Development and Principles and Techniques of Software Security are added, which are novel techniques of the application domain. That will also meet the requirement of engineering and industrial fields.

(2) Add the courses of engineering practice teaching. For instance, the courses of Research and Practices on Engineering, Tools and Environment Practices, as well as Process and Management of Software Outsourcing are added to training the students' capability of engineering and practice.

(3) Set up a series of rich and colorful extracurricular studies and extracurricular activities to encourage the students to make scientific research and to innovate, as well as to cultivate personalities.

After adjusting and optimizing the SE professional training program of PETOE, we evaluate the SE professional training program of PETOE based on the indicators made by the Undergraduate School of CSU again. Fig.3 shows the Comparison chart of key course teaching links before the adjustment and after the adjustment.

From the Fig.3, we can see that the credit of selected courses is 70 and its ratio of the total courses is $36.8 \%$, which is more than the requirement of $35 \%$. In addition, the credit of practice teaching courses is 59.5 and the ratio of the total courses is $31.2 \%$, which is also more than the requirement of $30 \%$. The credit of extracurricular study is 10 , which is equal to the requirement of 10. Obviously, the SE professional training program of PETOE after adjustment and optimization can meet of requirement of PETOE. 


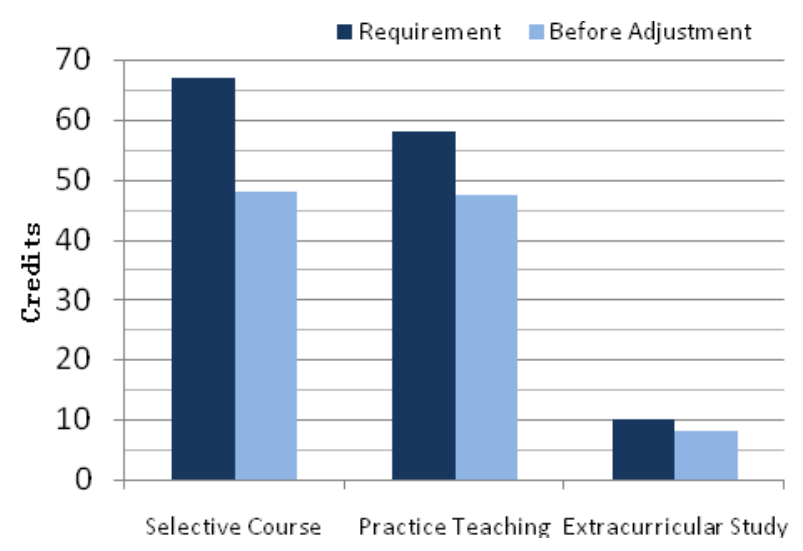

Fig.3.Comparison chart of key course teaching linksbefore adjustment and after adjustment

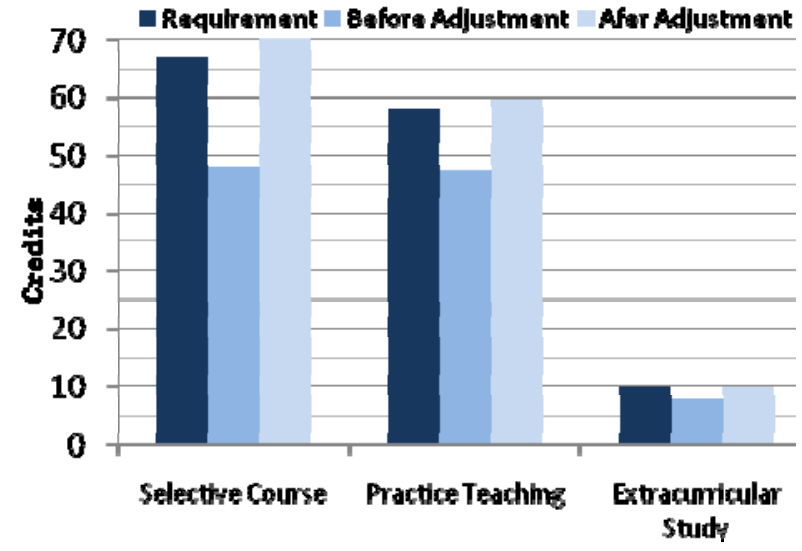

Fig.4. Key course teaching links before adjustment and after adjustment

\section{Conclusion}

This paper builds the GQM model for the professional training program of PETOE based on the national goal, the university goal and the professional goal of PETOE, and presents the metric model for formulating and evaluating the professional training program of PETOE. By the quantitative metric and analysis of the metric model, the method of adjusting and optimizing the professional training program of PETOE is proposed. The application in the software engineering major of PETOE shows that the GQM model for the professional training program of PETOE designed in this paper can effectively direct the process of developing, improving and optimizing the professional training program. The further work will focus on another key issue of PETOE, the training program of university-enterprise union training.

\section{References}

[1] LIN Jian, On the Professional Training Program of "A Plan for Educating and Training Outstanding Engineers”, Tsinghua Journal of Education, vol.32, no.2, pp.47-55, 2011.(in Chinese)

[2] LIN Jian, Restudy on the Professional Training Program of "A Plan for Educating and Training Outstanding Engineers”, Researches in Higher Education of Engineering, no.4, pp.10-17,57, 2011. (in Chinese)

[3] LIN Jian, The Development of General Standards for "A Plan for Educating and Training Outstanding Engineers”, Researches in Higher Education of Engineering, no.4, pp.21-29, 2010. (in Chinese)

[4] Basili,VR.,and Weiss,D., A Methodology for Collecting Valid Software Engineering Data, IEEE Transactions on Software Engineering, vol.SE-10, no.6, pp.728-738,1988.

[5] Li Dongsheng, Li Wenjun, and Mao Chen. On the In depth Cooperation Model in Engineering Education betweenUniversities and Enterprise, Researches in Higher Education of Engineering, no.3, pp.88-92, 2011. (in Chinese)

[6] Shengbing Ren, and Zhigang Hu, Teaching Reform and Practice on Fostering Engineering Capability for the Undergraduate Student, Information and Management Engineering, 2010. 